\title{
Ataxia in Institutionalized Patients with Epilepsy
}

\author{
G.B. Young, S.R. Oppenheimer, B.A. Gordon, G.A. Wells, L.P.A. Assis, \\ J.H. Kreeft, N.A. Lohuis and W.T. Blume
}

\begin{abstract}
Fifty-four per cent of 41 chronically institutionalized adult patients with epilepsy had ataxia of gait (wide mean stride width). None of the following correlated with stride width: serum phenytoin, previous phenytoin toxicity, seizure frequency, or status epilepticus. Seventeen of the 41 patients had computed tomographic head scans. Patients with radiological evidence of cerebellar atrophy had a wider mean stride width, later age of onset of seizures, greater peak serum concentrations of phenytoin than did those without cerebellar atrophy. Ataxia of gait was inconsistently associated with cerebellar atrophy. Elevated serum/plasma concentrations of phenytoin may be a risk factor for cerebellar atrophy, but seizure frequency or status epilepticus are not independently related to this complication.
\end{abstract}

\begin{abstract}
Résumé: L'ataxie chez les patients épileptiques qui sont institutionnalisés. Cinquante-quatre pourcent de 41 patients adultes en institution de soins prolongés avaient une ataxie à la marche (élargissement du polygone de base). La largeur des pas n'était corrélée à aucun des éléments suivants: le taux sanguin de phénytoïne, un épisode antérieur d'intoxication par la phénytoïne, la fréquence des crises ou un état de mal épileptique. Dix-sept parmi les 41 patients ont eu un CT scan cérébral. Chez les patients qui avaient des signes radiologiques d'atrophie cérébelleuse, la largeur moyenne des pas était plus grande, l'âge de début des crises était plus tardif et les pics de concentration de phénytoïne étaient plus hauts que chez ceux qui n'avaient pas d'atrophie cérébelleuse. L'atrophie cérébelleuse était associée de façon variable à l'ataxie à la marche. Des concentrations sériques/plasmatiques élevées de phénytoïne peuvent être un facteur de risque de l'atrophie cérébelleuse, mais la fréquence des crises ou l'état de mal épileptique ne sont par reliés de façon indépendante à cette complication.
\end{abstract}

Can. J. Neurol. Sci. 1994; 21: 252-258

The complication of severe, persistent ataxia imposes an additional handicap for the epileptic patient. ${ }^{1.2}$ With severe ataxia of any cause, independence is precluded and there is often serious morbidity: falls directly injure patients; the inactivity imposed by ataxia indirectly produces complications, both acute (e.g., deep venous thrombosis, pulmonary embolism and pneumonia) and chronic (e.g., bone demineralization, renal stones and contractures) ${ }^{3,4}$ Ataxic individuals are more likely to require institutionalized high level nursing care and more attention from other health care workers (physiotherapists, kinesthesiologists and physicians) than do non-ataxic patients. ${ }^{5}$ This, of course, adds to societal costs.

The first pathological observation of the occurrence of irreversible structural damage of the cerebellum in patients with epilepsy was made by Spielmeyer who described a diffuse loss of Purkinje cells and proliferation of Bergmann astroglia in the cerebellar cortex. ${ }^{6} \mathrm{~A}$ number of studies have confirmed these findings. ${ }^{7-11}$ The pathological series of Margerison and Corsellis $^{7}$ is of special interest as these authors studied a group of chronically institutionalized patients with epilepsy. They found 25 of 55 autopsied cases (45 per cent) showed cerebellar atrophy ranging from mild to moderate severity. There was no clinical correlation with their study, unfortunately, but it is likely a significant proportion would have been ataxic. The vermis as well as the hemispheres were affected.
The pathogenesis of persistent ataxia in epilepsy is controversial. The main hypotheses are frequent seizures, ${ }^{11}$ status epilepticus (with attendant hypoxia and other insults), ${ }^{12.13}$ damage from phenytoin (years of exposure or episodes of toxicity) ${ }^{14}$ and vitamin deficiency. ${ }^{15}$ Other metabolic derangements (e.g., vitamin deficiencies, mitochondrial diseases and excitatory amino acid damage) and trauma from falls should also be considered.

We elected to study a population of chronically institutionalized epileptic patients, as we have observed a number of such patients develop severe ataxia. Further, the important variables were known: medications were reliably administered; serum drug concentrations were regularly checked; episodes of status epilepticus were documented and there was a monthly tabulation of seizure frequency on each patient. Further, each patient had a documented annual physical examination by an in-hospital

From the Departments of Clinical Neurological Sciences (G.B.Y., S.R.O., W.T.B.), Biochemistry (B.A.G.), Radiology (L.P.A.A.) and Medicine (J.H.K.), Faculty of Medicine, the University of Westem Ontario; the Department of Biostatistics and Epidemiology (G.A.W.), Faculty of Medicine, the University of Ottawa and the University of Toronto (N.A.L.)

RECEIVED NOVEMBER 23, 1993. ACCEPTED IN FINAL FORM FEBRUARY 25, 1994. Reprint requests to: Dr. G.B. Young, Department of Clinical Neurological Sciences, Victoria Hospital, London, Ontario, Canada N6A 4G5. 
physician and the institution was visited by a neurologist regularly since 1975 .

Our objectives were to determine: 1 . the prevalence of significant ataxia in a sample population of institutionalized epileptic patients; 2 . whether the ataxia was related to cerebellar dysfunction rather than to dysfunction of other nervous structures; 3 . the strength of association of previously proposed risk factors with ataxia and cerebellar atrophy demonstrated on computed tomography (CT). From this, an assessment of the possible cause of the problem could be formulated and further studies for prevention might be initiated.

\section{Methods}

\section{Patient selection}

From over 200 chronically institutionalized epileptic patients, almost all of whom had long-standing mental subnormality, at the Oxford Regional Centre in Woodstock, Ontario, we selected 50 patients by numbering the charts and using a table of random numbers. From these 50 charts we included only those patients who had at least 5 seizures in their lifetime and who were institutionalized for more than 5 years. Informed consent was obtained from next-of-kin and, when feasible, from the patients.

Exclusion criteria were: co-existing neurological dysfunction which precluded adequate assessment of ataxia, e.g., quadriparesis or paraparesis, polyneuropathy with generalized areflexia, marked extra-pyramidal dysfunction or brain tumor; gross obesity; serious orthopedic deformity; severe general debility from systemic illness; recognized progressive syndromes/diseases known to cause both epilepsy and ataxia: progressive myoclonic epilepsies (to avoid patients with these syndromes, we excluded patients with myoclonic seizures, striking photic sensitivity on EEG or visual failure), cases in which ataxia preceded the development of seizures, subacute sclerosing panencephalitis, previously recognized amino acidopathies, juvenile Huntington's disease, Wilson's disease and storage disorders.

\section{Clinical Testing}

This was consistently performed before the first morning dose of anti-epileptic medication. Neurological examination was performed by S.R.O., who did not know the patients and who was blinded to the clinical and laboratory data. The following were tabulated: a clinical judgment regarding ataxia of upper and lower limbs and trunk, measurement of stride width (see Figure 1); ocular movement abnormalities (individually characterized); presence or absence of grasp, palmomental, snout, glabellar reflexes or paratonia, muscle atrophy, trophic skin changes, deep tendon reflexes; sensory exam (when possible), and an impression of motor function. Any other observations were tabulated as "other" on the data sheet.

\section{Blood samples}

Venous blood was taken immediately after the clinical exam, before the first daily dose of medication and before breakfast, for: serum concentrations of all current anti-epileptic drugs (free or unbound and total phenytoin concentrations were measured in patients on both phenytoin and valproate; phenobarbital was measured as well as primidone for patients on primidone), lactate, magnesium, vitamin $\mathrm{E}$, folate, plasma amino acids and red blood cell folate concentration.

\section{Chart review}

The following were tabulated from the patients' charts: age, sex, duration of seizure disorder, age of onset of seizures, and average and maximum number of seizures (divided into convulsive and nonconvulsive seizures) per year, episodes of generalized convulsive status epilepticus, previous toxicity with phenytoin (defined as serum concentration greater than $80 \mu \mathrm{mol} / \mathrm{L}$ ), all anti-epileptic drugs currently in use, EEG classification (generalized epileptiform activity, focal epileptiform activity, nonspecific, or normal). For the obviously ataxic patients, with stride widths of greater than $20 \mathrm{~cm}$, we examined the previous records to determine whether the ataxia was present on admission or was acquired and progressive during institutionalization. This was possible as: 1) all patients had a detailed admission and a yearly physical examination; 2) significant worsening of gait was commented upon in nursing and physician notes.

\section{Controls}

As stride width data were consistently available for all patients, the limits of normality for stride width for men and women were derived from a group of normal volunteers who were age and sex matched to the patient group. Controls had no history of neurological illness apart from migraine, were not on

\section{Determination of Mean Stride Width}

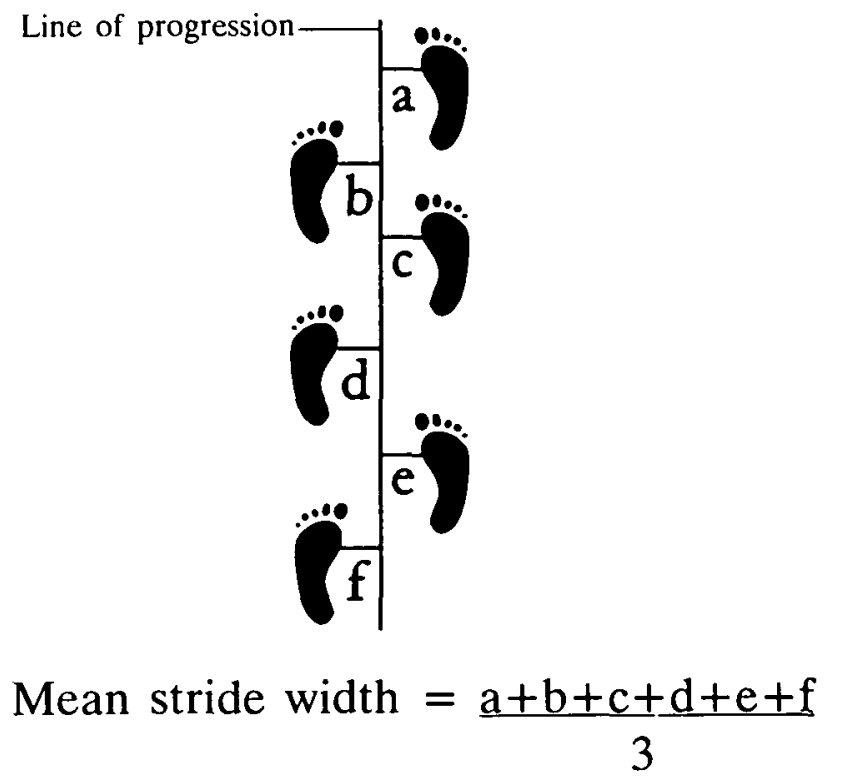

Figure 1. Determination of stride width. The patient walks in a straight line over a stretch of floor covered with baby powder. A string stretched between the right and left foot prints leaves the "line of progression" in the powder. Three measurements on each side are made from the medial border of the forefoot imprint to the line of progression. The mean stride width is the sum of these divided by $31=$ sum of 6 measurements divided by 6 then multiplied by 2 ). 
long-term medication, were less than 250 pounds in weight and had no orthopedic problems that interfered with gait. Control data for blood tests were available from the appropriate teaching hospital laboratory.

\section{Radiology}

Computed tomographic (CT) brain scans performed on patients within 5 years of the study were reviewed in a blinded (from any clinical information) fashion by LPAA who graded atrophy of the cerebellum and cerebrum as follows: $0=$ none, + $=$ slight or minimal, $++=$ mild,$+++=$ moderate and $++++=$ severe. The grading was verified by ranking the assembled scans against each other, still in a blinded manner, by LPAA.

\section{Statistical methods}

First, multiple linear regressions were performed for stride width as the main measure of ataxia with the other variables. Then, using the control values for stride width, the "ataxic group" of patients (with base width $2 \times \mathrm{SD}+$ mean of control data) were compared with "non-ataxic" patients (whose average stride width was less than $2 \times$ S.D. + mean) using t-tests. For the radiological ranking of atrophy two-tailed t-tests were used. For nonparametric data (e.g., past history of status epilepticus or phenytoin intoxication), Chi-square or Fisher's exact tests were applied.

\section{Results}

Forty-one institutionalized epileptic patients met our criteria. There were 23 men and 18 women who ranged in age from 25 81 years with mean of 48 years. Stride width measurement was the only consistently available clinical assessment of cerebellar function and was, therefore, used as the principal index of ataxia. Forty-one normal controls were matched for sex and \pm 5 years for age to develop normative data for stride width. These values were used to construct the normal range for stride width for males and females: the mean (standard deviation) for men was $6.12(3.2) \mathrm{cm}$ and $3.6(2.6) \mathrm{cm}$ for women. The upper limits of normal (2 x standard deviation + mean) were $12.5 \mathrm{~cm}$ for men and $8.8 \mathrm{~cm}$ for women. Based on these normative data, 22 $(54 \%)$ of the patients, or $10(43 \%)$ of the men and $12(67 \%)$ of the women, were ataxic $(p>0.05)$. From our chart review, all those who were clinically ataxic with stride widths of more than $20 \mathrm{~cm}$ had been documented to have worsening of gait.

Mean time of institutionalization was 23 years (S.D. 12 years) and mean duration of epilepsy was 40 years (S.D. 15 years). All patients had been on phenytoin for some years; 28 were still on the drug at the time of the study.

Eighteen of the $22(82 \%)$ had frontal release signs (positive glabellar tap, snout, forced grasping, rooting or palmomental), mild peripheral neuropathy or both. This did not significantly differ from the non-ataxic group: 14 of 19 (74\%).

Linear regression analysis (Table 1) failed to show any significant association of any of the variables with measured stride width. Similarly when ataxic and non-ataxic (defined by stride width) groups were compared (Table 2), there were no significant findings. (The mean peak serum phenytoin in the charts was over twice as high in the ataxic group as the non-ataxic group. However, because of the large standard deviation, the difference was not significant.)
CT scans were performed on 17 patients (Table 3 ). Cerebellar atrophy was more common in the ataxic patients, as defined by stride width $(p<0.05)$. However, some with cerebellar atrophy were not ataxic and some without cerebellar atrophy were ataxic. Cerebral atrophy $(+$ to ++$)$ was present in 7 ataxic patients with cerebellar atrophy, but cerebellar atrophy occurred without cerebral atrophy in 8 others who were ataxic. Thus, the ataxia was likely of cerebellar origin at least in the latter 8 patients. Those with generalized cerebellar atrophy had higher peak levels of phenytoin in the past than did those without cerebellar atrophy $(\mathrm{p}<0.05)$ (See Table 3). Although all of those patients who had been toxic on phenytoin in the past had cerebellar atrophy, not all those with cerebellar atrophy had documented phenytoin toxicity.

Serum concentrations of anti-epileptic drugs other than phenytoin (carbamazepine, 15 patients; primidone, 13 patients;

Table 1. Linear Regression Analysis.

Comparing Average Stride Width with Other Variables in Patient Population

\begin{tabular}{ccc}
\hline Variable & Correlation & $\begin{array}{c}\text { P Value for 2-Tailed } \\
\text { Significance }\end{array}$ \\
\hline
\end{tabular}

age of seizure onset

$-0.09$

0.591

Average No.

convulsions/yr.

$-0.2403$

Average No.

nonconvulsive seizures/yr.

0.3386

0.236

Maximum No. convulsive

seizures/yr.

Maximum No.

nonconvulsive seizures/yr.

0.918

Phenytoin toxicity

$-0.2014$

Peripheral neuropathy

0.121

0.945

Vitamin E

0.1751

0.300

Magnesium

0.2511

0.146

Phenytoin

when examined (28)

0.0624

0.752

Phenytoin free fraction (5)

0.5437

0.344

Phenobarbital (30)

0.2689

0.151

Valproate (9)

0.5561

0.120

Carbamazepine (15)

$-0.1215$

0.666

Lactate

0.3008

0.070

folate

0.2041

0.226

( ) refers to number of patients on whom test performed, given when less than total population.

Values for all chemical compounds relate to serum or plasma concentrations. 
phenobarbital, 30 patients; valproate, 9 patients; ethosuximide, 1 patient only) did not correlate with stride width or significantly differ between the ataxic and non-ataxic groups or between those with and without cerebellar atrophy on CT scans.

When consideration was given to the effects of multiple testing, there were no definite differences in amino acid measurements between ataxic and non-ataxic groups. Notably, there was no correlation of stride width with any amino acid and there was no difference between ataxic and non-ataxic groups or between those with and those without cerebellar atrophy with respect to serum concentrations of glutamate, aspartate, or taurine or with glutamate/taurine or aspartate/taurine ratios.

\section{Discussion}

We found that 54 per cent of chronically institutionalized patients with epilepsy had ataxia of gait. Clinically and radiologically this appeared to be cerebellar in origin for the majority of, but not all, affected individuals. This population is at significant risk for gait ataxia and cerebellar degeneration.

The variables are reviewed in turn, comparing our findings with those in the literature:

\section{Seizure frequency}

We did not find a statistically significant association between the frequency and seizure-years of convulsive seizures and cerebellar atrophy. This is in contradistinction to a study by Dam ${ }^{11}$ who studied the loss of cerebellar Purkinje cells on postmortem examinations of 32 institutionalized patients with epilepsy. He found that all 6 patients with $\geq 1$ grand mal seizure per week had a significantly reduced density of Purkinje cells compared to controls. Others with less frequent seizures had inconsistent loss of Purkinje cells.

Theoretically, seizures may produce loss of Purkinje cells, without status epilepticus or hypoxia, by glutamic acid activation of alpha-amino-3-hydroxy-5-methylisoxazolepropionic acid (AMPA)/quisqualate receptors. This is based on the following experimental data: a) Julien and Laxer ${ }^{16}$ showed that when penicillin-induced epileptiform bursts occurred in the cat sigmoid gyrus, there was a high frequency (up to $150 \mathrm{~Hz}$ ) discharge of Purkinje cells in the contralateral perivermal region of the cerebellum. This was followed by more generalized Purkinje cell firing throughout the cerebellar cortex. b) Glutamic acid can act as an "excitotoxic" neurotransmitter, damaging neurons when its extracellular concentration reaches a critical level. ${ }^{17-19} \mathrm{c}$ ) There is a strong glutaminergic input into the cerebellum via climbing and parallel fibres. ${ }^{20-22}$ d) Neuronal death has been shown to relate to increased calcium entry into neurons. ${ }^{23}$ In the cerebellum this may relate to glutamate activation of AMPA/quisqualate receptors on Purkinje, basket, stellate and Golgi cells.24.25 (Activation of $\mathrm{N}$-methyl $\mathrm{D}$-aspartate [NMDA] channels may account for excitotoxic damage in the hippocampus, cerebral cortex, and cerebellar granule cells ${ }^{26}$ but other cerebellar cortical neurons have mainly AMPA/ quisqualate rather than NMDA receptors.) ${ }^{27}$ e) The AMPA antagonist CNQX prevents death of motor neurons in tissue culture when exposed to cerebrospinal fluid from patients with motor neuron disease. ${ }^{28}$ Similarly pretreatment with 1 (aminophenyl)-4-methyl-7,8-methylenedioxy-5H-2,3-benzodiazepine (which blocks the AMPA/quisqualate receptor)
Table 2. Separate Variance Using T-Test.

\begin{tabular}{lll}
\hline Variable & $\begin{array}{l}\text { Ataxic Group } \\
\text { (SD) }\end{array}$ & $\begin{array}{l}\text { Non-Ataxic } \\
\text { Group }\end{array}$ \\
& $22[10 \mathrm{M}: 12 \mathrm{~F}]$ & (SD) $19[13 \mathrm{M}: 6 \mathrm{~F}]$ \\
\hline
\end{tabular}

Age of seizure onset $38(13) \quad 42$ (17) $\quad 0.98(39)$, NS

Av. No. convulsions

$19(32)$

$19(28)$

0.03 (39), NS

Av. No. nonconv.

seizures/year

$10(17)$

$2.7(7)$

$1.83(39), \mathrm{NS}$

Proportion with status epilepticus

0.5

0.4

$0.91(37)$, NS

Max. Phenytoin

conc. $(\mu \mathrm{mol} / \mathrm{L})$

$76.14(60)$

$37(61)$

$1.96(36), \mathrm{NS}$

Serum Phenytoin

$(\mu \mathrm{mol} / \mathrm{L})$

when entered

$63(27)$

$52(29)$

1.09 (29), NS

Vitamin $\mathrm{E}(\mu \mathrm{mol} / \mathrm{L}) \quad 28(8)$

$25(6)$

1.04 (38), NS

Serum folate

(nmol/L)

$11(9)$

9 (3)

0.68 (39), NS

NS = not significant

Table 3. Cerebellar Atrophy and other Variables.

\begin{tabular}{llll}
\hline Variable & $\begin{array}{l}\text { Cerebellar } \\
\text { Atrophy (S.D.) }\end{array}$ & $\begin{array}{l}\text { No. Cerebellar } \\
\text { Atrophy (S.D.) }\end{array}$ & T Value (df) \\
\hline $\begin{array}{l}\text { Age of onset of } \\
\text { seizures (years) }\end{array}$ & $42(9.5)$ & $28(18)$ & $2.24(15)^{*}$ \\
$\begin{array}{l}\text { Av. No. convulsions } \\
\text { per year }\end{array}$ & $30(43)$ & $24(29)$ & $0.28(15)$ \\
$\begin{array}{l}\text { Av. No. } \\
\text { Nonconv. sz./yr. }\end{array}$ & $11(16)$ & $4(6)$ & $0.86(15)$ \\
$\begin{array}{l}\text { Proportion with } \\
\text { status epilepticus }\end{array}$ & 0.64 & 0.4 & $0.85(14)$ \\
$\begin{array}{l}\text { Peak phenytoin } \\
\text { conc. prior to } \\
\text { study ( } \mu \text { mol/L) }\end{array}$ & $82.6(62)$ & $21(13)$ & $2.68(14)^{*}$ \\
$\begin{array}{l}\text { Serum folate } \\
\text { (nmol/L) }\end{array}$ & $10.6(11)$ & $9.2(7.5)$ & $0.25(15)$ \\
$\begin{array}{l}\text { Serum } \\
\text { phenytoin }(\mu \mathrm{mol} \\
\text { per litre) } \\
\text { when entered }\end{array}$ & $68.3(31.4)$ & $52.7(22.5)$ & $0.90(13)$ \\
\hline $\begin{array}{l}* \\
\text { p }<0.05\end{array}$ & & & \\
\hline
\end{tabular}


decreased neurotoxic damage, seizures and ataxia in rats given B-N-methylamino-alanine (BMAA, an excitotoxic chemical). ${ }^{29}$ BMAA has been shown to cause cerebellar dysfunction and degeneration of cerebellar stellate, basket, Purkinje and Golgi cells. ${ }^{30}$

\section{Phenytoin}

We found that ataxic patients with cerebellar atrophy on CT scan more commonly had previous phenytoin toxicity than those without such a history.

It has been difficult in the clinical literature to separate phenytoin from seizures as the factor with the strongest association with cerebellar atrophy in epileptic patients. All of the patients in our study and that of Dam ${ }^{11}$ had been on phenytoin and the patients with more frequent or prolonged seizures tended to receive higher doses and have higher serum concentrations. Our study suggests that phenytoin may be a risk factor independent of seizure frequency. This is supported by the study of Botez and colleagues who found that in a group of outpatients with epilepsy, the accumulated dose of phenytoin was related to CT-demonstrated cerebellar-brainstem atrophy while the number of seizures was not. ${ }^{31}$

There is however some evidence that phenytoin can damage the cerebellum independently of seizures: a) Cerebellar ataxia and degeneration have been reported in patients who did not have epilepsy who took phenytoin for years. ${ }^{14}$ b) Kokenge and colleagues $^{32}$ showed that prolonged, high dose phenytoin therapy could cause loss of Purkinje cells. Marked species differences between cats and rats, ${ }^{26}$ were found, however, casting some doubt on the relevance of these studies to humans. ${ }^{26,33}$ Early reports of ultrastructural changes in Purkinje cells from animals treated with phenytoin ${ }^{34}$ may have overlooked fixation artifact. ${ }^{11}$ The matter has not been resolved.

It appears that phenytoin toxicity or exposure may cause or contribute to but is not essential for cerebellar damage in patients with epilepsy. Most, but not all of the clinical cases of chronic cerebellar ataxia, atrophy or Purkinje cell loss in epileptic patients have followed the advent of phenytoin as an antiepileptic drug in 1938. In some cases the ataxia was described as being reversible and dose-related, ${ }^{35,36}$ while in other cases ataxia and radiologically-demonstrated cerebellar degeneration are persistent. ${ }^{37.38}$ In these clinical cases of ataxia in epileptic patients on phenytoin, minimal-to-no improvement in ataxia occurred when phenytoin was reduced or withdrawn. ${ }^{32.37-39}$ Iivanainen and colleagues ${ }^{40}$ found the degree of cerebellar atrophy on pneumoencephalography was related to the severity of phenytoin intoxication in a group of mentally retarded adult epileptics, but the importance of seizure frequency or status epilepticus was not weighed.

There is some theoretical support for increased susceptibility of epileptic patients for phenytoin-induced cerebellar damage. Using the Julien and Laxer ${ }^{16}$ model, phenytoin administration was found to increase the spontaneous firing rate of Purkinje cells. ${ }^{41}$ Cerebral cortical epileptiform activity is reduced and more sustained Purkinje cell discharges in the range of $240 \mathrm{~Hz}$ can be recorded. Thus seizures and phenytoin independently alter cerebellar function by markedly increasing Purkinje cell firing. The combination may accentuate damage either acutely from increased entry of sodium and chloride as a consequence of depolarization with osmotic disruption of the neuron or delayed neuronal death may occur with increased calcium entry into nerve cells, with proteolysis of neurofilaments, disruption of mitochondria or breakdown of membrane phospholipids and release of arachidonic acid. ${ }^{18}$

\section{Status epilepticus}

We did not find any association of ataxia or cerebellar atrophy with a previous history of status epilepticus. The literature also fails to show much support for this association. Cerebellar degeneration has been described in patients on long term phenytoin who have not had status epilepticus. ${ }^{42}$ In the biopsy study of Salcman and colleagues ${ }^{10}$ only 2 of 5 patients who showed severe degeneration on cerebellar biopsy, had ever had status epilepticus; two had never even had a grand mal convulsion. Meldrum's group ${ }^{12}$ found proliferation of Bergmann astroglia in cerebellar cortex in 2 of 14 baboons in which convulsive status epilepticus was induced with the convulsant drug allylglycine. This group also found cerebellar abnormalities were not seen if the animals were paralyzed and ventilated, with support of blood gases, blood pressure, serum glucose and temperature. ${ }^{13}$

\section{Nutritional and Metabolic Disorders}

We did not find any difference in glutamate, aspartate or taurine between ataxic and non-ataxic population, or, for that matter between patients and normal controls. This is in contrast to the observations of Van Gelder and colleagues ${ }^{43}$ who found that plasma of patients with $3 / \mathrm{sec}$ spike and wave epilepsy has higher levels of glutamic acid and lower levels of aspartic acid and taurine than that of controls. An increased plasma glumatate/taurine ratio was found in patients with primary generalized as well as in patients with partial epileptic seizures by Janjua and colleagues. ${ }^{44}$ Cerebellar dysfunction was not commented upon in these studies, nor was the severity of the epilepsy correlated with the glutamate/taurine ratio.

We did not find any patients who fit well into the inherited mitochondrial disorders such as MELAS (mitochondrial encephalopathy, lactic acidosis and stroke-like episodes) or MERFF (myoclonic epilepsy and ragged-red fibres). ${ }^{45}$ Although congenital mitochondrial dysfunction is unlikely, we cannot exclude the possibility of acquired mitochondrial disease. Mitochondrial DNA deletions may occur after hypoxic or other insults in various tissues. ${ }^{46}$ Phenytoin is a potent inhibitor of lactic dehydrogenase, a mitochondrial enzyme. ${ }^{47}$ It is uncertain whether chronic phenytoin toxicity produces cellular damage as a result.

Also, we did not find any association of folate deficiency with ataxia or cerebellar atrophy. Only a few patients had lower than normal serum concentrations of folate. Muñoz-Garcia and colleagues ${ }^{5}$ have shown a correlation of low serum folate levels with the development of trunkal ataxia in patients with epilepsy. The authors attributed the ataxia to drug-induced folate deficiency. Other factors such as the duration of the seizure disorder and the numbers of antiepileptic drugs, however, also correlated with ataxia. Prolonged treatment with phenytoin, phenobarbital and primidone ${ }^{48}$ or carbamazepine $e^{49}$ can produce a significant reduction in serum folate levels; in their out-patient population, the deficiency may have related to concomitant use of these drugs as well as nutritional and socio-economic factors. Nutritional deficiency was not a factor in our patients who were regularly fed in the same institution; none was eating poorly. 
Also, it is possible that each of these factors may have correlated with other unexamined entities, such as the frequency of seizures or episodes of prolonged seizures, which were of greater etiological importance.

\section{Trauma}

The incidence of major head injury, either clinically or radiologically defined, was not greater among the ataxic individuals. Some patients in the ataxic group wore helmets and had healed scars and soft tissue swellings principally under the chin, supraorbital ridges and the occipital region. Further, there was not a significant increase in frontal lobe signs or in radiological evidence of frontal lobe trauma in the ataxic patients.

The cerebellum is not vulnerable to trauma; ${ }^{50}$ head injuryrelated ataxia is likely to be related to damage to supratentorial structures.

Further studies are needed to examine the etiology of cerebellar degeneration in patients with epilepsy. A wide stride width is not always related to cerebellar degeneration. To address the issue of cerebellar degeneration in a similar population, it is probably best to rely on neuro-imaging. This deserves further study. In view of the high risk of the institutionalized epileptic population for gait problems and cerebellar atrophy, it is best to avoid sustained high serum phenytoin concentrations in such individuals.

\section{ACKNOWLEDGEMENT}

This project was funded by a grant (\#02140) from the Ontario Ministry of Health.

\section{REFERENCES}

1. Minogue SJ, Latham O. Cerebellar degeneration with epilepsy. Med J Australia 1945; 1: 430-433.

2. Haberland C. Cerebellar degeneration with clinical manifestations in chronic epileptic patients. Psychiatr Neurol (Basel.) 1962; 143: $29-44$.

3. Victor M, Adams RD, Mancall EL. A restricted form of cerebellar cortical degeneration occurring alcoholic patients. Arch Neurol 1959; 1: 577-688.

4. Landis DM, Rosenberg RN, Landis SC, Schut L, Nyhan WL. Olivopontocerebellar degeration. Clinical and ultrastructural abnormalities. Arch Neurol 1974; 31: 295-307.

5. Nichols PJR. Rehabilitation of the severely disabled. 2 Management. London: Butterworths, 1971: 1-18.

6. Spielmeyer W. Über einige Beziehungen zwischen Ganglienzellveränderungen und gliösen Erscheinungen, besonders im Kleinhirn. Ztscr f d ges Neurol u Psychiat 1920; 54: 1- 38.

7. Margerison JH, Corsellis JAN. Epilepsy and the temporal lobes: a clinical, electroencephalographic and neuropathological study of the brain in epilepsy, with particular reference to the temporal lobes. Brain 1966; 89: 499-530.

8. Norman RN. The neuropathology of status epilepticus. Med Sci Law 1964; 4: 46-51.

9. Zimmerman HM. The histopathology of convulsive disorders in children. J Pediatr 1938; 13: 859-880.

10. Salcman M, Defendini R, Correll J, Gilman S. Neuropathological changes in cerebellar biopsies of epileptic patients. Ann Neurol 1978; 3: 10-19.

11. Dam M. The density and ultrastructure of the Purkinje cells following diphenylhydantoin treatment in animals and man. Acta Neurol Scand 1972; 48 (Suppl 49): 12-63.

12. Meldrum BS, Horton RW, Brierley JB. Epileptic brain damage in adolescent baboons following seizures induced by allylglycine. Brain 1974; 97: 407-418.
13. Meldrum BS, Vigouroux RA, Brierley JB. Systemic factors and epileptic brain damage. Prolonged seizures in paralyzed, artificially ventilated baboons. Arch Neurol 1973; 29: 82-87.

14. Rapport RL, Shaw CM. Phenytoin-related cerebellar degeneration without seizures. Ann Neurol 1977; 2: 437-439.

15. Muñoz-Garcia D, Ser TD, Bermejo F, Portera A. Truncal ataxia in chronic anticonvulsant treatment. J Neurol Sci 1982; 55: 305311.

16. Julien RM, Laxer KD. Cerebellar responses to penicillin-induced cerebral cortical epileptiform discharge. Electroencephalogr Clin Neurophysiol 1974; 37: 123-132.

17. Lucas DR, Newhouse JP. The toxic effect of sodium L-glutamate on the inner layers of the retina. AMA Arch Ophthalmol 1957; 58: $193-201$.

18. Olney JW. Neurotoxicity of excitatory amino acids. $I n$ : McGeer EG, Olney JW, McGeer PL, eds. Kainic Acid as a Tool in Neurobiology. New York: Raven, 1978.

19. Rothman SM, Olney JW. Glutamate and the pathophysiology of hypoxic-ischemic brain damage. Ann Neurol 1986; 19: 105-111.

20. McGeer PL, McGeer EG. Amino acid neurotransmitters. In: Siegel GL, Albers RW, Agranoff BW, Katzman R, eds. Basic Neurochemistry, 3rd edition. Boston: Little, Brown and Co., 1981: 249

21. Ottersen OP, Zhang N, Walberg F. Metabolic compartmentation of glutamate and glutamine: morphological evidence obtained by quantitative immunocytochemistry in rat cerebellum. Neuroscience 1992; 46: 519-534.

22. Zhongqi JI, AAs J-E, Lakke J, Walberg F, Ottersen OP. An electron microscopic, immunogold analysis of glutamate and glutamine in terminals of rat spinocerebellar fibres. J Comp Neurol 1991; 307: 296-310.

23. Olney JW, Collins RC, Sloviter RS. Excitotoxic mechanisms of epileptic brain damage. Adv Neurol 1986; 44: 857-877.

24. Watkins JC, Evans RH. Excitatory amino acid transmitters. Ann Rev Pharmacol Toxicol 1981; 21: 165-204.

25. Zhang N, Ottersen OP. In search of the identity of the cerebellar climbing fiber transmitter: immunocytochemical studies in rats. Can J Neurol Sci 1993; 20 (Suppl 3): S36-S42.

26. Rabe CS, Tabakoff B. Glycine site-directed agonists reverse the actions of ethanol at the $\mathrm{N}$-methyl-D-aspartate receptor. Mol Pharmacol 1990; 38: 753-757.

27. Garthwaite J. Glutamate, nitric oxide and cell-cell signalling in the nervous system. Trends Neurosci 1991; 14: 60-67.

28. Couratier P, Hugon J, Sindou P, Vallat JM, Dumas M. Cell culture evidence for neuronal degeneration in amyotrophic lateral sclerosis being linked to glutamate AMPA/kainate receptors. Lancet 1993; 341: 265-268.

29. Smith SE, Meldrum BS. Receptor site specificity for the acute effects of $B-N$-methlamino-alanine in mice. Eur $J$ Pharmacol 1990; 187: 131-134.

30. Weiss JH, Koh JY, Choi DW. Neurotoxicity of B-N-methlaminoalanine (BMAA) and B-N-oxalyl-amino-Lalanine (BOAA) on cultured cortical neurons. Brain Res 1989; 497: 64-69.

31. Botez MI, Attig E, Vézina JL. Cerebellar atrophy in epileptic patients. Can J Neurol Sci 1988; 15: 299-303.

32. Kokenge R. Kutt H, McDowell F. Neurological sequelae following Dilantin overdose in a patient and in experimental animals. Neurology 1965; 15: 823-829.

33. Puro DG, Woodward DJ. Effects of diphenylhydantoin on activity of rat cerebellar Purkinje cells. Neuropharmacology 1973; 12: 433-440.

34. Alcaca H, Lertaanangkoon K, Stenbach W, Kellaway P, Horning MG. The Purkinje cell in phenytoin intoxication: ultrastructural and Golgi studies. Pharmacologist 1978; 20: 240-249.

35. Botez MI, Gravel J, Attig E, Vezina J-L. Reversible chronic cerebellar ataxia after phenytoin intoxication. Neurology 1985; 35 : 1152-1157.

36. Kutt H, Winters W, Kokenge R, McDowell F. Diphenylhydantoin metabolism, blood levels and toxicity. Arch Neurol 1964; 11: 642-648.

37. Riley CG. Chronic hydantoin intoxication: case report. NZ Med J 1972; 76: 425-428. 
38. Selhorst JB, Kaufman B, Horwitz SJ. Diphenyhyldantoin-induced cerebellar degeneration. Arch Neurol 1972; 27: 453-455.

39. Ghatak NR, Santoso RA, McKinney WM. Cerebellar degeneration following long-term phenytoin therapy. Neurology 1976; 26: 818-820.

40. Iivanainen $M$, Viukari $M$, Helle E-P. Cerebellar atrophy in phenytoin-treated mentally-retarded epileptics. Epilepsia 1977; 18: 375-386.

41. Halpern L, Julien R. Augmentation of cerebellar Purkinje cell discharge after diphenylhydantoin. Epilepsia 1972; 13: 377-385.

42. McLain LW, Martin JT, Allen JH. Cerebellar degeneration due to chronic phenytoin therapy. Ann Neurol 1980; 7: 18-23.

43. Van Gelder NM, Janjua NA, Metrakos K, MacGibbin B, Metrakos JD. Plasma amino acids in $3 / \mathrm{sec}$ spike and wave epilepsy. Neurochem Res 1980; 6: 659-671.

44. Janjua NA, Andermann E, Eeg-Olofsson O, et al. Plasma glutamic acid elevation in epileptic patients and their relatives. Epilepsia 1986; $27: 615$.
45. Berkovic SF, Andermann F, Carpenter S, Wolfe LS. Progressive myoclonic epilepsies: specific causes and diagnoses. $\mathrm{N}$ Eng J Med 1986; 315: 296-305.

46. Wallace DC. Mitochondrial diseases: genotype versus phenotype. Trends Genet 1993; 9: 128-133.

47. Dzimiri N, Almotrefi AA. Investigation of class I anti-arrhythmic drug actions on guinea-pig cardiac mitochondrial lactate dehydrogenase activity. Clin Exp Pharmacol Physiol 1993; 20: 201206.

48. Reynolds EH. Chronic antiepileptic toxicity - a review. Epilepsia 1975; 16: 319-352.

49. Reizenstein P, Lund L. Effects of anticonvulsive drugs on folate absorption and the cerebrospinal folate pump. Scand J Haematol 1973; 11: 158-165.

50. Dow RS, Moruzzi G. The Physiology and Pathology of the Cerebellum. Minneapolis: University of Minnesota Press, 1958. 